\title{
EFEK EKSTRAK ETANOL BIJI LABU KUNING (Cucurbita moschata Duchesne) SEBAGAI ANTELMINTIK PADA CACING GELANG (Ascaridia galli)
}

\section{EFFECTS OF YELLOW PUMPKIN (Cucurbita moschata Duchesne) ETHANOL EXTRACT AS AN ANTELMINTIC ON ROUNDWORM (Ascaridia galli)}

\author{
Noni Zakiah $^{1 *}$, Vonna Aulianshah ${ }^{1}$, T. Maulana Hidayatullah ${ }^{1}$, Faridah Hanum ${ }^{1}$ \\ ${ }^{1}$ Jurusan Farmasi, Poltekkes Kemenkes Aceh \\ Jl. Soekarno-Hatta Kampus Terpadu Poltekkes Aceh, Darul Imarah Aceh Besar, Aceh, Indonesia \\ *email: nonizakiah1981@gmail.com
}

\begin{abstract}
ABSTRAK
Kegunaan labu kuning di Indonesia masih sebatas daging buah yang dapat diolah menjadi panganan seperti kue basah, kolak dan sayur berkuah. Secara empiris, biji labu kuning telah digunakan untuk mengatasi cacingan. Penelitian ini dilakukan untuk mengetahui mortalitas cacing gelang (Ascaridia galli) dalam ekstrak etanol biji labu kuning (Cucurbita moschata Duchesne). Penelitian ini menggunakan 25 ekor Ascaridia galli yang dibagi menjadi 5 kelompok, kelompok I kontrol negatif menggunakan larutan $\mathrm{NaCl}$ fisiologis, kelompok II kontrol positif menggunakan larutan pirantel pamoat 0,5\%, kelompok III, IV dan $\mathrm{V}$ berturut-turut menggunakan $25 \mathrm{mg} / \mathrm{ml}, 50 \mathrm{mg} / \mathrm{ml}$ dan $100 \mathrm{mg} / \mathrm{ml}$ ekstrak etanol biji labu kuning. Parameter penelitian ini ditentukan dengan melihat persentase nilai skor pasca inkubasi 12 jam, 24 jam, dan 36 jam. Skor 3 diberikan apabila seluruh tubuh Ascaridia galli bergerak, skor 2 diberikan jika hanya sebagian tubuh Ascaridia galli bergerak, skor 1 jika Ascaridia galli diam tetapi masih hidup, dan skor 0 apabila Ascaridia galli mati. Hasil uji in vitro dengan perlakuan $25 \mathrm{mg} / \mathrm{ml}$ ekstrak etanol biji labu kuning menyebabkan kematian 3 ekor Ascaridia galli atau 60\% pasca inkubasi 36 jam, sedangkan ekstrak etanol biji labu kuning dengan perlakuan $50 \mathrm{mg} / \mathrm{ml}, 100 \mathrm{mg} / \mathrm{ml} \mathrm{dan}$ kelompok kontrol positif mengakibatkan kematian 4 ekor Ascaridia galli atau $80 \%$ pasca inkubasi 36 jam. Dari hasil penelitian disimpulkan bahwa ekstrak etanol biji labu kuning (Cucurbita moschata Duchesne) dosis $25 \mathrm{mg} / \mathrm{ml}, 50$ $\mathrm{mg} / \mathrm{ml}$, dan $100 \mathrm{mg} / \mathrm{ml}$ secara in vitro dalam waktu 36 jam mampu mengakibatkan mortalitas Ascaridia galli.
\end{abstract}

Kata kunci: labu kuning, cacing gelang (Ascaridia galli), mortalitas

\begin{abstract}
The use of yellow pumpkin in Indonesia is still limited to fruit meat that can be processed into snacks such as soggy cakes, porridge and vegetable soup. This research was conducted to determine the mortality of Ascaridia galli in ethanol extract of yellow pumpkin seeds (Cucurbita moschata Duchesne). This study used 25 Ascaridia galli which were divided into 5 groups, group I was negative control using physiological $\mathrm{NaCl}$ solution, group II was positive control using $0.5 \%$ pirantel pamoate solution, group III, IV and V respectively used $25 \mathrm{mg} /$ $\mathrm{ml}, 50 \mathrm{mg} / \mathrm{ml}$ and $100 \mathrm{mg} / \mathrm{ml}$ ethanol extract of yellow pumpkin seeds. The parameters of this study were determined by looking at the percentage of postincubation scores 12 hours, 24 hours, and 36 hours. A score of 3 is given if the whole body of Ascaridia galli moves, a score of 2 is given if only part of the
\end{abstract}


body of Ascaridia galli moves, a score of 1 if Ascaridia galli is still but still alive, and a score of 0 if Ascaridia galli dies. In vitro test results with $25 \mathrm{mg} / \mathrm{ml}$ ethanol extract of pumpkin seeds caused 3 deaths of Ascaridia galli or $60 \%$ after incubation for 36 hours, while ethanol extract of yellow pumpkin seeds treated with $50 \mathrm{mg} / \mathrm{ml}, 100 \mathrm{mg} / \mathrm{ml}$ and positive control group resulting in the death of 4 Ascaridia galli or $80 \%$ after 36 hours incubation. From the results of the study concluded that the ethanol extract of yellow pumpkin seeds (Cucurbita moschata Duchesne) doses of $25 \mathrm{mg} / \mathrm{ml}, 50 \mathrm{mg} / \mathrm{ml}$, and $100 \mathrm{mg} / \mathrm{ml}$ in vitro within 36 hours can lead to Ascaridia galli mortality.

Keywords: yellow pumpkin, roundworm (Ascaridia galli), mortality

\section{PENDAHULUAN}

Infeksi cacing merupakan suatu masalah pada negara berkembang dengan iklim tropis dan subtropis serta disertai sistem sanitasi lingkungan yang kurang memadai. ${ }^{1,2}$ Infeksi cacing adalah penyakit yang diakibatkan oleh beberapa jenis cacing. Diantara cacing gastrointestinal terdapat sejumlah spesies yang ditularkan melalui tanah (soil transmitted helminth) seperti cacing gelang (Ascaris lumbricoide dan Strongyloides stercoralis), cacing tambang (Ancylostoma duodenale dan Necator americanus) dan cacing cambuk

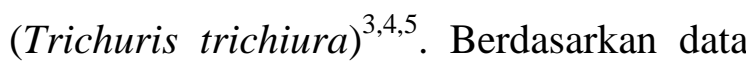
organisasi kesehatan dunia sekitar 1,5 miliar orang atau sekitar $20 \%$ dari total populasi dunia menderita infeksi cacing. ${ }^{6}$

Rata-rata prevalensi infeksi cacing di Indonesia mencapai lebih dari $28 \%$ dengan tingkat yang berbeda-beda di tiap daerahnya. Tingginya prevalensi cacingan di Indonesia tidak terlepas dari iklim tropis yang memungkinkan beberapa jenis cacing tumbuh dan berkembang. ${ }^{7}$ Beberapa studi tentang angka cacingan di beberapa wilayah
Indonesia diantaranya penelitian yang dilakukan oleh Kartini, menyebutkan bahwa persentase cacingan di SDN Kecamatan Rumbai Pesisir Pekanbaru sebanyak 16,25\% dengan jenis infeksi yang terbanyak adalah cacing Ascaris lumbricoides $(12,91 \%) .{ }^{8}$ Studi serupa juga dilakukan pada siswa SD di Distrik Arso Kabupaten Keerom Papua yang menunjukkan infeksi cacingan sebesar 29,9\%. ${ }^{9}$ Studi di kota Palu juga menunjukkan prevalensi cacingan pada anak sebesar $31,6 \%{ }^{10}$ dan angka cacingan pada murid kelas IV, V, VI pada dua SD di Kabupaten Grobogan adalah sebesar $13,7 \% .^{11}$

Cacing gelang merupakan nematoda yang berada di usus. Infeksi cacing ini dikenal dengan istilah askariasis yang menyebabkan anak atau orang dewasa menjadi kekurangan gizi, ${ }^{12}$ terhambatnya perkembangan fisik, menurunkan kecerdasan dan produktivitas kerja ${ }^{13}$ serta meningkatkan angka kejadian anemia. ${ }^{14,15,16}$

Salah satu tanaman yang banyak dibudidaya di Indonesia adalah labu kuning 
(Cucurbita moschata Duchesne), karena labu kuning dapat tumbuh di tempat lembab maupun kering (daerah tropis). Buah labu kuning adalah jenis tanaman yang mudah tumbuh dan tidak sulit baik dari segi pembibitannya dan perawatannya, hasilnya pun cukup memberikan nilai ekonomis untuk masyarakat. ${ }^{17}$

Penggunaan biji labu sebagai pengobatan tradisional sudah dilakukan oleh penduduk asli Amerika. Biji labu telah digunakan sebagai agen antelmintik dan pengobatan suportif dalam gangguan fungsional kandung kemih. ${ }^{18,19,20}$ Penggunaan labu kuning di Indonesia masih sebatas daging buah yang diolah menjadi panganan seperti kue basah, kolak dan sayur berkuah dengan biji yang dibuang percuma. $^{21}$ Tujuan penelitian ini adalah membuktikan pengaruh ekstrak etanol biji labu kuning (Cucurbita moschata Duchesne) terhadap mortalitas cacing Ascaridia galli.

\section{METODE}

Penelitian bersifat eksperimental dilaksanakan di Laboratorium Mikrobiologi Jurusan Farmasi Poltekkes Kemenkes Aceh. Cacing yang digunakan 25 ekor cacing Ascaridia galli yang dibagi menjadi 5 kelompok. Setiap kelompok menggunakan 5 ekor cacing Ascaridia galli. Cacing yang dipilih adalah cacing dewasa berukuran 7-11 cm yang tidak tampak cacat secara anatomi.
Pada langkah persiapan ekstrak etanol biji labu kuning, sebanyak 200 gr serbuk simplisia biji labu kuning diekstraksi menggunakan metode maserasi dengan pelarut etanol 70\%. Maserat diuapkan menggunakan vacum rotary evaporator. Ekstrak dibuat dalam 3 konsentrasi yaitu 25 $\mathrm{mg} / \mathrm{ml}, 50 \mathrm{mg} / \mathrm{ml}$, dan $100 \mathrm{mg} / \mathrm{ml}$.

Setiap ekstrak dibuat dalam larutan $\mathrm{NaCl}$ sebanyak $25 \mathrm{ml}$. Langkah kedua dibuat larutan pirantel pamoat dalam konsentrasi $0,5 \%$ dalam $100 \mathrm{ml} \mathrm{NaCl}$. Kemudian dilakukan uji in vitro cacing Ascaridia galli dengan membagi sebanyak 25 ekor menjadi 5 kelompok perlakuan, masing-masing kelompok menggunakan 5 ekor cacing. Kelompok 1 kontrol negatif larutan $\mathrm{NaCl}$, kelompok 2 kontrol positif larutan pirantel pamoat $0,5 \%$, kelompok 3 ekstrak etanol biji labu kuning $25 \mathrm{mg} / \mathrm{ml}$, kelompok 4 ekstrak etanol biji labu kuning $50 \mathrm{mg} / \mathrm{ml}$ dan kelompok 5 ekstrak etanol biji labu kuning $100 \mathrm{mg} / \mathrm{ml}$. Perlakuan dilakukan dengan cara merendam cacing Ascaridia galli di dalam larutan ekstrak pada cawan petri sebanyak $25 \mathrm{ml}$, diinkubasi pada suhu $41^{\circ} \mathrm{C}$. Pengamatan dilakukan setiap 12 jam selama 36 jam. Skor 3 diberikan apabila seluruh tubuh cacing bergerak. Skor 2 diberikan apabila hanya sebagian tubuh cacing bergerak. Skor 1 diberikan apabila cacing tidak bergerak (diam) tetapi masih hidup. Skor 0 diberikan apabila cacing tidak bergerak (mati). ${ }^{22}$ 


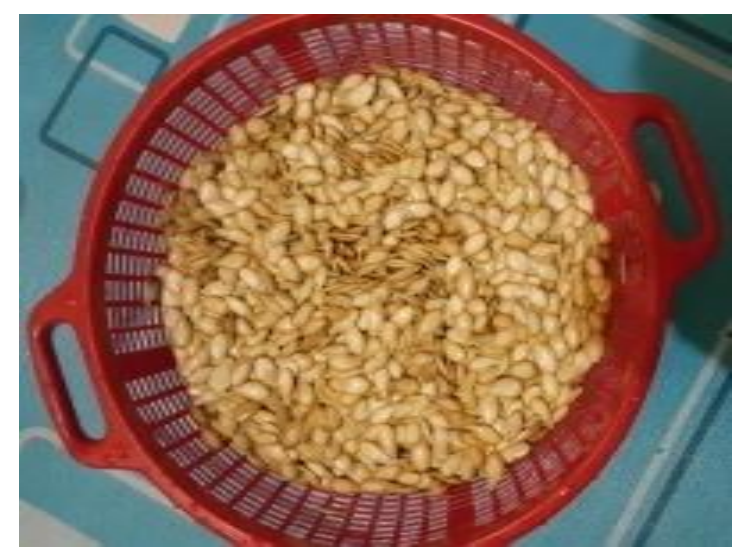

Gambar 1. Biji labu kuning

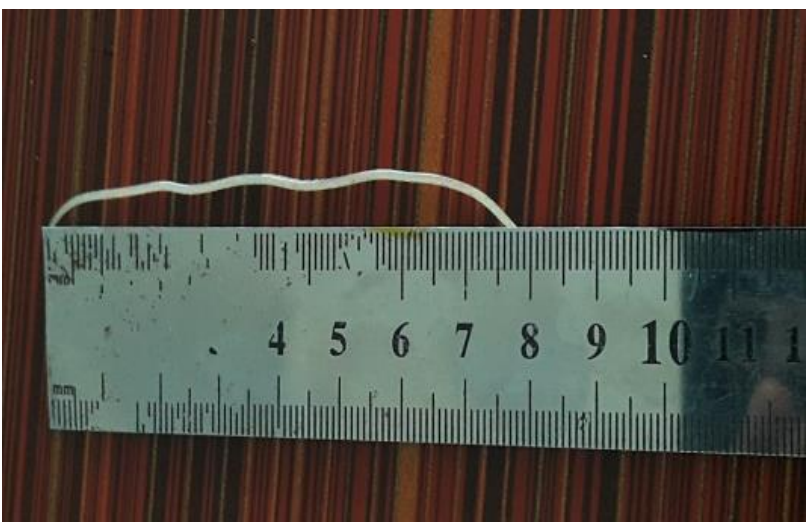

Gambar 3. Cacing Ascaridia galli

\section{HASIL}

Pengamatan motilitas hingga menyebabkan mortalitas cacing Ascaridia galli ditentukan dengan menghitung persentase nilai skor pasca inkubasi 12 jam, 24 jam, dan 36 jam. Skor 3 diberikan apabila seluruh tubuh cacing Ascaridia galli

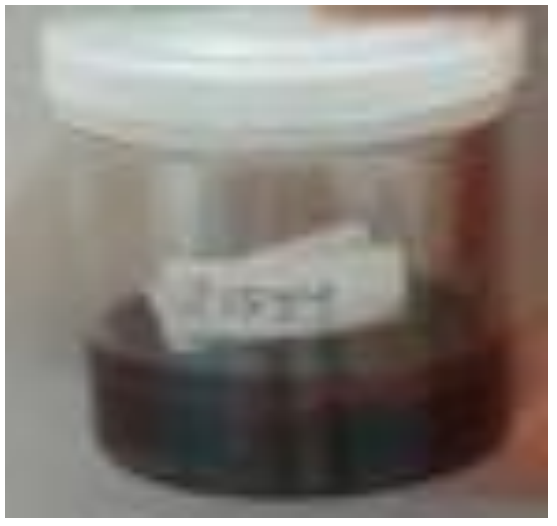

Gambar 2. Ekstrak Etanol Biji Labu Kuning (EEBLK)

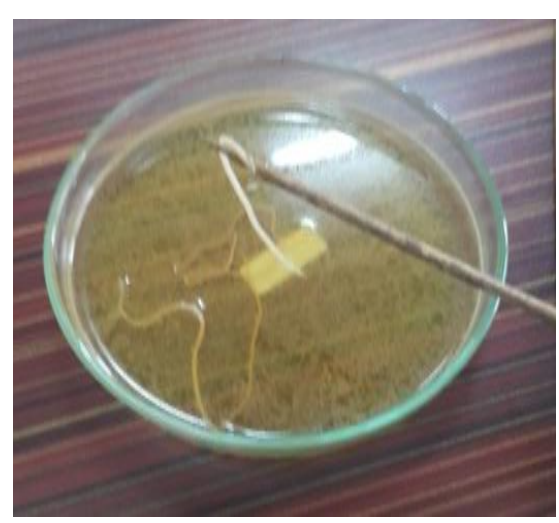

Gambar 4. Cacing Ascaridia galli direndam di dalam larutan EEBLK

bergerak, skor 2 diberikan jika sebagian tubuh Ascaridia galli bergerak, skor 1 jika Ascaridia galli tidak bergerak (diam) tetapi masih hidup, dan skor 0 apabila Ascaridia galli mati. ${ }^{8}$ Hasil uji persentase skor cacing Ascaridia galli disajikan pada Tabel 1. 
Tabel 1. Hasil persentase skor Ascaridia galli pasca inkubasi

\begin{tabular}{|c|c|c|c|c|c|c|c|c|c|c|c|c|}
\hline \multirow{4}{*}{ Kelompok } & \multicolumn{12}{|c|}{ Persentase (\%) skor cacing Ascaridia galli } \\
\hline & \multicolumn{4}{|c|}{ Inkubasi 12 jam } & \multicolumn{4}{|c|}{ Inkubasi 24 jam } & \multicolumn{4}{|c|}{ Inkubasi 36 jam } \\
\hline & Skor & Skor & Skor & Skor & Skor & Skor & Skor & Skor & Skor & Skor & Skor & Skor \\
\hline & 3 & 2 & 1 & 0 & 3 & 2 & 1 & 0 & 3 & 2 & 1 & 0 \\
\hline Kontrol (-) $\mathrm{NaCl}$ & $\begin{array}{c}5 \\
(100)\end{array}$ & & & & $\begin{array}{c}5 \\
(100)\end{array}$ & & & & & $\begin{array}{c}2 \\
(40)\end{array}$ & $\begin{array}{c}2 \\
(40)\end{array}$ & $\begin{array}{c}1 \\
(20)\end{array}$ \\
\hline Kontrol (+) & & & 5 & & & & 1 & 4 & & & 1 & 4 \\
\hline Pirantel Pamoat & & & (100) & & & & (20) & (80) & & & (20) & (80) \\
\hline $25 \mathrm{mg} / \mathrm{ml}$ & 2 & 1 & 2 & & & & 2 & 3 & & & 2 & 3 \\
\hline EEBLK & (40) & (20) & (40) & & & & (40) & (60) & & & (40) & (60) \\
\hline $50 \mathrm{mg} / \mathrm{ml}$ & 1 & 1 & 3 & & & & 2 & 3 & & & 1 & 4 \\
\hline EEBLK & (20) & (20) & (60) & & & & (40) & $(60)$ & & & (20) & (80) \\
\hline $\begin{array}{c}100 \mathrm{mg} / \mathrm{ml} \\
\text { EEBLK }\end{array}$ & $\begin{array}{c}1 \\
(20)\end{array}$ & & $\begin{array}{c}4 \\
(80)\end{array}$ & & & & $\begin{array}{c}5 \\
(100)\end{array}$ & & & & $\begin{array}{c}1 \\
(20)\end{array}$ & $\begin{array}{c}4 \\
(80)\end{array}$ \\
\hline
\end{tabular}

Keterangan:

Skor $3 \quad$ : Seluruh tubuh Ascaridia galli bergerak

Skor $2 \quad$ : Hanya sebagian tubuh Ascaridia galli bergerak

Skor $1 \quad$ : Ascaridia galli tidak bergerak (diam) tetapi masih hidup

Skor $0 \quad$ : Ascaridia galli sudah mati

EEBLK : ekstrak etanol biji labu kuning

\section{PEMBAHASAN}

Pada penelitian ini sampel yang digunakan yaitu cacing Ascaridia galli dewasa dengan ukuran 7-11 cm, tidak tampak cacat secara anatomi dan masih aktif bergerak. Cacing Ascaridia galli diperoleh dari Laboratorium Parasitologi Fakultas Kedokteran Hewan Universitas Syiah Kuala Banda Aceh.

Pada Tabel 1 terlihat bahwa hasil penelitian in vitro menunjukkan pada kelompok kontrol negatif cacing Ascaridia galli masih bertahan hidup dimana seluruh tubuhnya masih bergerak skor $3100 \%$ pasca inkubasi 12 jam dan 24 jam, selanjutnya skor $240 \%$, skor $140 \%$, dan skor $020 \%$ pasca inkubasi 36 jam. Penurunan motilitas cacing Ascaridia galli hingga menyebabkan mortalitas pada kontrol negatif disebabkan karena cacing tidak berada pada tubuh inangnya, sehingga Ascaridia galli tidak mendapatkan asupan makanan. Para peneliti terdahulu juga menyatakan bahwa, Ascaridia galli telah mati $50 \%$ pada larutan $\mathrm{NaCl}$ pasca inkubasi 36 jam. Ascaridia galli hanya mampu bertahan hidup selama 48 jam dalam medium tanpa perlakuan apapun. ${ }^{22}$

Pada kelompok kontrol positif pirantel pamoat skor $1100 \%$ pasca inkubasi 12 jam, skor $120 \%$ dan skor 080 $\%$ pasca inkubasi 24 jam, sedangkan pasca inkubasi 36 jam, Ascaridia galli masih sama hasilnya seperti pasca inkubasi 24 jam. Ascaridia galli pada kelompok kontrol positif mati dikarenakan berdasarkan mekanisme kerja obat dari pirantel pamoat yaitu dengan meningkatkan pelepasan 
asetilkolin, menghambat kolinesterase, dan merangsang neuron ganglionik, memberikan efek penghambatan neuromuskuler pada cacing. Hal ini menyebabkan depolarisasi luas pada membran otot cacing, yang mengakibatkan ketegangan pada otot cacing, sehingga menyebabkan kelumpuhan (paralisis) pada otot cacing. ${ }^{23}$

Pada kelompok EEBLK $25 \mathrm{mg} / \mathrm{ml}$ skor $340 \%$, skor $220 \%$, skor $140 \%$ pasca inkubasi 12 jam, skor $140 \%$, skor $060 \%$ pasca inkubasi 24 jam, sedangkan pasca inkubasi 36 jam masih sama hasilnya dengan pasca inkubasi 24 jam. Pada kelompok EEBLK $50 \mathrm{mg} / \mathrm{ml}$ skor $320 \%$, skor $220 \%$, skor $160 \%$ pasca inkubasi 12 jam, skor $140 \%$, skor $060 \%$ pasca inkubasi 24 jam, skor $120 \%$, skor $080 \%$ pasca inkubasi 36 jam. Pada kelompok EEBLK 100 mg/ml skor 3 20\%, skor $180 \%$ pasca inkubasi 12 jam, skor $1100 \%$ pasca inkubasi 24 jam, skor $120 \%$ dan skor 0 $80 \%$ pasca inkubasi 36 jam.

Berdasarkan hasil penelitian EEBLK $25 \mathrm{mg} / \mathrm{ml}$ menyebabkan kematian 3 ekor cacing atau $60 \%$ pasca inkubasi 36 jam, kelompok EEBLK dengan perlakuan $50 \mathrm{mg} / \mathrm{ml}$ dan $100 \mathrm{mg} / \mathrm{ml}$ mengakibatkan kematian 4 ekor cacing atau $80 \%$ pasca inkubasi 36 jam, maka dapat dikatakan bahwa ekstrak etanol biji labu kuning dapat mengakibatkan mortalitas cacing Ascaridia galli. Hal ini senada dengan studi yang dilakukan oleh Salehi dkk (2019) yang menyatakan bahwa Cucurbita dapat digunakan pada pengobatan infeksi parasit intestinal. $^{18}$ Studi lain terhadap cacing kremi (Aspiculuris tetraptera) juga memberikan efek serupa. ${ }^{24}$

Efek antelmintik biji labu kuning diduga berasal dari kandungan zat aktifnya, yaitu tanin, ${ }^{25}$ yang bekerja dengan cara menggumpalkan protein pada cacing. ${ }^{26}$ Selain tanin, biji labu kuning juga mengandung alkaloid berberin dan palmatin yang bekerja menghambat enzim kolinesterase dan memberikan efek paralisis pada otot. 27,28,29 Hasil penelitian ini menunjukkan bahwa biji labu memiliki aktivitas anthelmintik yang tinggi terhadap nematoda dan mempunyai prospek untuk dikembangkan sebagai senyawa obat baru.

\section{KESIMPULAN}

Ekstrak etanol biji labu kuning (Cucurbita moschata Duchesne) $25 \mathrm{mg} / \mathrm{ml}$, $50 \mathrm{mg} / \mathrm{ml}$, dan $100 \mathrm{mg} / \mathrm{ml}$ secara in vitro pada waktu 36 jam mampu mengakibatkan mortalitas terhadap cacing Ascaridia galli.

\section{SARAN}

Untuk peneliti berikutnya dapat melakukan pengujian antelmintik secara in vivo.

\section{KONTRIBUSI PENULIS}

Kontribusi penulis pada artikel ini yaitu, NZ bertanggung jawab melaksanakan 
penelitian, mengumpulkan referensi, VA mendiskusikan hasil penelitian bersama tim pakar. TMH berkontribusi dalam membantu bagian analisa data, metode serta perbaikan bahasa dalam artikel dan membantu proses diskusi hasil, FH menulis manuskrip jurnal dan F membantu menata administrasi jurnal sesuai template.

\section{UCAPAN TERIMAKASIH}

Ucapan terimakasih kepada Ketua Jurusan Farmasi Poltekkes Kemenkes Aceh yang telah memfasilitasi penggunaan Laboratorium Mikrobiologi.

\section{DAFTAR PUSTAKA}

1. WHO. Intestinal worms. https://www.who.int/intestinal_worms/ en/. Published 2019. Accessed November 20, 2019.

2. Hedley L, Serafino RL. Helminth infections: diagnosis and treatment. Pharm J. 2015, Vol. 295, No. 7882, pp. 1-17. doi:10.1211/pj.2015.20069529

3. Barer MR, Irving WL, Swan A, Perera N. Helminths : Intestinal worm infections; filariasis; schistosomiasis; hydatid disease. In: Medical Microbiology: A Guide To Microbial Infections. 19th ed. China: Elsevier; 2018.

4. Esan OO, Uwalaka EC, Apampa MT. Prevalence of gastrointestinal helminths of waterfowls and its possible public health implications in Ibadan, Nigeria. Sokoto J Vet Sci. 2018, Vol. 16, No. 3, pp. 76-79. doi:10.4314/sokjvs.v16i3.12

5. WHO. Guideline: Preventive Chemotheraphy To Control SoilTransmitted Helminth Infections In AtRisk Population Groups. Spain; 2017. doi:10.1017/CBO9781107415324.004

6. Jourdan PM, Lamberton PHL, Fenwick
A, Addiss DG. Soil-transmitted helminth infections. Lancet. 2018, Vol. 391, No. 10117, pp. 252-265. doi:10.1016/S0140-6736(17)31930-X

7. Agustina D. "Cacingan" Bukan Lagi Penyakit Orang Kampung. CNN Indonesia. 2015.

8. Kartini S. Kejadian Cacingan pada Siswa Sekolah Dasar Negeri Kecamatan Rumbai Pesisir Pekanbar. $J$ Kesehat Komunitas. 2016, Vol. 3, No. 2, pp. 53-58. doi:10.25311/jkk.vol3.iss2.102

9. Sandy S, Sumarni S, Soeyoko. Analisis Model Faktor Risiko Yang Mempengaruhi Infeksi Kecacingan Yang Ditularkan Melalui Tanah Pada Siswa Sekolah Dasar Di Distrik Arso Kabupaten Keerom, Papua. Media Litbangkes. 2015, Vol. 25,No. 1,pp. 114.

10. Chadijah S, Sumolang PPF, Veridiana NN. Hubungan Pengetahuan, Perilaku, Dan Sanitasi Lingkungan Dengan Angka Cacingan Pada Anak Sekolah Dasar Di Kota Palu. Media Penelit dan Pengemb Kesehat. 2014,Vol. 24, No. 1, pp. 50-56. doi:10.22435/mpk.v24i1.3487.50-56

11. Halleyantoro R, Riansari A, Dewi DP. Insidensi Dan Analisis Faktor Risiko Infeksi Cacing Tambang Pada Siswa Sekolah Dasar Di Grobogan, Jawa Tengah. J Kedokt Raflesia. 2019, Vol. 5 No. 1, pp. 18-27.

12. Irmayanti. Hubungan Asupan Makanan dan Infeksi Cacingan Dengan Status Gizi Pada Anak SD Inpres Bakung. 2013.

13. Menkes RI. Peraturan Menteri Kesehatan Republik Indonesia No. 15 Tahun 2017 Tentang Penanggulangan Cacing. Jakarta. 2017.

14. Galvao FC. Anemia in patients with intestinal parasitic infection. Rev Ibero.... 2011, Vol. 70, No. 2, pp. 206-211.

15. Adebara OV, Ernest SK, Ojuawo IA. Association between Intestinal Helminthiasis and Serum Ferritin Levels Among School Children. Open 
J Pediatr. 2011, Vol. 01, No. 02,pp. 12-16. doi:10.4236/ojped.2011.12004

16. Darlan DM, Ananda FR, Sari MI, Arrasyid NK, Sari DI. Correlation between iron deficiency anemia and intestinal parasitic infection in schoolage children in Medan. IOP Conf Ser Earth Environ Sci. 2018,Vol. 125, No. 1. doi:10.1088/1755$1315 / 125 / 1 / 012059$

17. Suprapti ML. Awetan Kering Dan Dodol Waluh. Yogyakarta: Kanisius; 2005.

18. Salehi B, Capanoglu E, Adrar N, et al. Cucurbits plants: A key emphasis to its pharmacological potential. Molecules. 2019, Vol. 24, No. 10, pp. 1-23. doi:10.3390/molecules24101854

19. Hargono D. Manfaat Biji Labu (Cucurbita Sp.) Untuk Kesehatan. Media Litbangkes. 1999, Vol. 9 No. 2, pp. 3-7.

20. Wong C. 5 Natural Remedies for Intestinal Parasites. Verywell health. https://www.verywellhealth.com/natura 1-remedies-for-intestinal-parasites88232. Published 2019. Accessed November 20, 2019.

21. JPNN. Biji Labu Kuning Ternyata Banyak Manfaatnya Buat Kesehatan. https://www.jpnn.com/news/biji-labukuning-ternyata-banyak-manfaatnyabuat-kesehatan?page $=4$. Published 2019. Accessed November 20, 2019.

22. Balqis U, Hamzah A, Daud R, Hambal M, Harris A. Motilitas Ascaridia galli Dewasa dalam Larutan Ekstrak Etanol Biji Palem Putri ( Veitchia merrillii). Agripet. 2016, Vol. 16, No. 1, pp. 9-15.

23. Martin R, Geary T. Pharmacology of Pyrantel. In: Marchiondo AA, ed. Pyrantel Paraciticide Therapy In
Humans and Domestic Animals. London: Sara Tenney; 2016.

24. Ayaz E, Gökbulut C, Coșkun H, Türker A, Özsoy Ş, Ceylan K. Evaluation of the anthelmintic activity of pumpkin seeds (Cucurbita maxima) in mice naturally infected with Aspiculuris tetraptera. $J$ Pharmacogn Phyther. 2015, Vol. 7, No. 9, pp. 189-193. doi:10.5897/JPP2015.0341

25. Sharma A, Sharma AK, Chand T, Khardiya M, Yadav KC. Preliminary Phytochemical Evaluation of Seed Extracts of Cucurbita maxima Duchesne. J Pharmacogn Phytochem. 2013, Vol. 2, No. 3, pp. 62-65.

26. Adamczyk B, Simon J, Kitunen V, Adamczyk S. Tannins and Their Complex Interaction with Different Organic Nitrogen Compounds and Enzymes: Old Paradigms versus Recent Advances. Chem Open. 2017, Vol. 6, Np. 5, pp. 610-614. doi:10.1002/open.201700113

27. Grzybek M, Kukula-Koch W, Strachecka A, et al. Evaluation of anthelmintic activity and composition of pumpkin (Cucurbita pepo L.) seed extracts - in vitro and in vivo studies. Int J Mol Sci. 2016, Vol. 17, No. 9, pp. 1-21. doi:10.3390/ijms17091456

28. Kaline S, Chaves M, Feitosa CM. Pharmacological activities palmatine alkaloid compound isolated from Guatteria friesiana prospects for new drug development . Asian J Biomed Pharm Sci. 2017, Vol. 6, No. 59, pp. 35-39.

29. Singh N, Sharma B. Toxicological effects of berberine and sanguinarine. Front Mol Biosci. 2018, Vol. 5, No. 21, pp. 1-7. doi:10.3389/fmolb.2018.00021 